\title{
The scope of U.S. state soil health legislation: A mixed-methods policy analysis
}

\author{
Madison N. Delmendo, ${ }^{\text {a }}$ Yona Sipos, ${ }^{\mathrm{b}}$ David R. Montgomery c \\ University of Washington, Seattle \\ Ryan P. Coled \\ Oregon State University, Corvallis \\ Jennifer J. Otten e* \\ University of Washington, Seattle
}

Submitted December 4, 2019 / Revised February 18 and October 4, 2020, and January 12 and 19, 2021 /

Accepted January 21, 2021 / Published online May 6, 2021

Citation: Delmendo, M. N., Sipos, Y., Montgomery, D. R., Cole, R. P., \& Otten, J. J. (2021). The scope

of U.S. state soil health legislation: A mixed-methods policy analysis. Journal of Agriculture, Food Systems,

and Community Development, 10(3), 69-90. https://doi.org/10.5304/jafscd.2021.103.001

Copyright $(C) 2021$ by the Authors. Published by the Lyson Center for Civic Agriculture and Food Systems. Open access under CC-BY license.

\begin{abstract}
Links between soil health and public health are established and growing in the scientific literature, and soil health bills in the U.S. have increased since

a Madison Delmendo, MS, RD, Nutritional Sciences Program, School of Public Health, University of Washington; 330 Raitt Hall; Seattle, WA 98105 USA; delmendm@uw.edu

b Yona Sipos, Ph.D., Nutritional Sciences Program, Department of Environmental and Occupational Health Sciences, School of Public Health, University of Washington; 306 Raitt Hall; Seattle, WA 98105 USA; +1-206-616-2680; ysipos@,uw.edu

${ }^{c}$ David Montgomery, Ph.D., Department of Earth and Space Sciences, University of Washington; Box 351310; Seattle, WA 98195 USA; +1-206-685-2560; bigdirt@uw.edu

d Ryan Cole, MS, OSU Water Resources Graduate Program, College of Forestry, Oregon State University; 280 Peavy Hall; Corvallis, OR 97330 USA; ryan.cole@,oregonstate.edu

e * Corresponding author: Jennifer Otten, Ph.D., RD, Nutritional Sciences Program, Center for Public Health Nutrition, Department of Environmental and Occupational Health Sciences, School of Public Health, University of Washington; 306c Raitt Hall; Seattle, WA 98105 USA; +1-206-221-8233; jotten@uw.edu
\end{abstract}

2016, but the extent to which current soil health legislation addresses public health implications has not been examined. Does the scope of current legislation explicitly address links to public health? This question will grow more pressing as population growth places higher demands on soils. In this study, we examine the scope and content of recent soil health legislation and investigate the importance of context, processes, and actors through semistructured interviews with soil health profes-

\section{Statement on Any Previous Reporting of Data}

These findings have not been previously published. The findings in this manuscript have not appeared elsewhere, but a pre-edited version of the manuscript was published on the University of Washington ProQuest Dissertation and Thesis database in 2019.

\section{Conflict of Interest}

The authors report no conflicts of interest and have had full control of all primary data and agree to allow the journal to review data if requested.

\section{Funding}

This work was not funded and was conducted in fulfillment of Ms. Delmendo's thesis. The content is solely the responsibility of the authors. 
sionals involved with identified bills. Twelve bills from 11 states were analyzed and 10 interviews were conducted. Legislation focused primarily on soils' capacity to sequester carbon and improve water quality, while public health had minimal representation. Interviews illuminated themes such as climate change motivating bill proposals and recognition of soils as living ecosystems, yet also demonstrated structural and knowledge limitations to including public health in soil health policies. These findings provide a novel perspective on the scope and passage of soil health legislation and demonstrate the opportunity for broader collaboration with public health.

\section{Keywords}

Soil Health, Public Health, Legislation, Policy, Policy Analysis

\section{Introduction}

Since 2016, the introduction of agricultural policies targeting soil health in U.S. state legislatures has increased. Prior to 2016 only two U.S. states had proposed legislation regarding soil health. By August 2019, overall state legislatures had seen over 20 proposals related to soil health. Along with the addition of soil health language to the 2018 federal farm bill, this increase suggests a turning point in soil conservation efforts (Soil Health Institute, 2020). Usage of the term "soil health" is also a relatively new phenomenon in the scientific community. In 1996, soil researchers Doran, Sarrantonio, and Liebig defined soil health as the "continued capacity of soil to function as a vital living system, within ecosystem and land-use boundaries, to sustain biological productivity, maintain the quality of air and water environments, and promote plant, animal, and human health" (Doran, Sarrantonio, \& Liebig, 1996, p. 11). This definition has since become standard language among researchers (Bennett, Mele, Annett, \& Kasel, 2010; Larkin, 2015; Moebius-Clune et al., 2016, p. 12) and was adopted by the U.S. National Resource Conservation Service (NRCS) in 2012 (NRCS, 2018).

While the language around and the interest in the concept of soil health is relatively new, U.S. soil conservation policies date back to the 1930s dust bowl (NRCS, 2020b). During this time, conservation policies focused mainly on mitigating topsoil erosion (Dumanski, 2015; NRCS, 2020b). Since the early $20^{\text {th }}$ century, the scientific understanding of the role of microorganisms in sequestering atmospheric carbon has greatly advanced understanding of soil as a complex system, facilitating development of conservation as more than a concern with erosion (Lal, 2004; Schmidt et al., 2011). Intensive farming practices common to the U.S. industrial agricultural system, such as frequent tillage, synthetic pesticide and fertilizer application, and largescale monoculture, have been found to degrade soil ecosystems and health (Matson, Parton, Power, \& Swift, 1997). Appreciation of the complex processes of soil led to promotion of new soil management practices as a way to mitigate climate and soil degradation (Doran \& Zeiss, 2000; Lal, 2004). Practices to enhance soil health include no-till and low-till systems, crop rotation, addition of compost and organic fertilizers, polycultures, and cover cropping (National Soils Survey Center, 2015). Programs incentivizing these practices began to emerge in national conservation policy. In the late 1990s to early 2000s, the Environmental Quality Incentives Program and Conservation Stewardship Program established financial and technical assistance to help farmers implement and maintain soil conservation practices (Environmental Quality Incentives Program, 2016; NRCS, 2020a). In 2014 the NRCS created a Soil Health Division as a way to strategically manage national efforts to improve soil health (NRCS, 2020b). The 2018 Farm Bill included soil health in national initiatives through expanded funding for incentive programs, specifically promoting crop rotation, cover cropping, and rotational grazing (Agricultural Improvement Act, 2018). The Bill also allocated additional funds for on-farm demonstration trials and grant funding for soil health research (Harrigan \& Charney, 2018).

As soil health policies have evolved, so has the understanding of soil's connection to human health. At the most basic level, soil is the foundation for almost all agriculture and food production, yet the breadth of ecosystem services that soil provides reaches far beyond agriculture itself. Soil serves as a biofilter protecting drinking water supplies from contaminants such as pesticides, heavy 
metals, pathogens, and nitrates (Keesstra et al., 2012). Airborne dust from agricultural soils can carry pathogens, synthetic chemicals, heavy metals, and animal waste particulates that can cause respiratory irritation and lung tissue damage (Brevik \& Burgess, 2014). Healthy soils are less erodible by wind and, therefore, create less particulate matter detrimental to air quality (Brevik \& Burgess, 2014). By limiting the spread of pathogens through air and water, soil plays a role in human disease control (Brevik \& Burgess, 2014; Wall, Nielsen, \& Six, 2015). Healthy soils can also help protect communities from the hazardous effects of floods and droughts, while degraded soils worsen the effects of such natural events (Basche, 2017). Soil degradation that reduce yields has led to greater application of chemical fertilizers, which have been linked to increased risk of certain cancers, birth defects, and thyroid conditions (Tan, Lal, \& Wiebe, 2005; Ward, 2009). In terms of crop nutrients, the research linking soil health to nutrient quality of fruits and vegetables is limited. However, evidence suggests soil microbes can increase the ability of crops to take up soil nutrients, thereby increasing the nutrient content of food for human consumption (Antunes et al., 2012). Humans rely on soils to provide many ecosystem services, demonstrating the paradox that anthropogenic activities cause much soil degradation, yet soils are also necessary for preserving public health.

While the evolution of federal soil conservation policy promotes many aspects of soil health as defined by the scientific community, inclusion of healthy soil's role in promoting human health is limited. The 2018 Farm Bill connects soil to human health only in the consideration that soil testing can prevent food contamination (Agricultural Improvement Act, 2018). The recent increase of soil health legislation at the state level provides an opportunity to widen the scope of such policies, yet the extent to which current state soil health legislation neglects public health represents a potential gap which will only grow more pressing as population growth places increasing demands on soil in the future (Cumming et al., 2014; Tilman, Balzer, Hill, \& Befort, 2011). At the same time, pressures from climate change will continue to contribute to degradation and loss of soil, lessening agricultural capacity to meet growing needs (Amundson et al., 2015; Tilman et al., 2011). Including a public health focus in soil health legislation could enhance public health benefits of soil stewardship and help mitigate future threats to soil ecosystem services.

The aims of this research are two-fold: to assess the scope of recently introduced U.S. state soil health legislation and to identify opportunities to better connect soil health and public health in state-level soil health legislation. To achieve these aims, we used the Health Policy Triangle (Walt \& Gilson, 1994) to assess 12 bills proposed in U.S. state legislation from 2016 to 2019, of which three had passed prior to this study, three passed during project analysis, and six remained in legislative committee as of August, 2019 at the project's culmination.

\section{Methodology}

\section{Policy Framework}

We assessed the current scope of U.S. state soil health legislation through document review and semistructured interviews. Walt and Gilson's Health Policy Triangle (HPT) was chosen as a theoretical framework to inform and structure study design. The HPT (Figure 1) consists of four policy components which must all be working synergistically for policies to be effective: content, context, process, and actors (Walt \& Gilson, 1994). For this project, content is the text of legislation documents and context is the environmental or situational circumstances in which policy processes occur, in-

\section{Figure 1. Walt and Gilson's Health Policy Triangle}

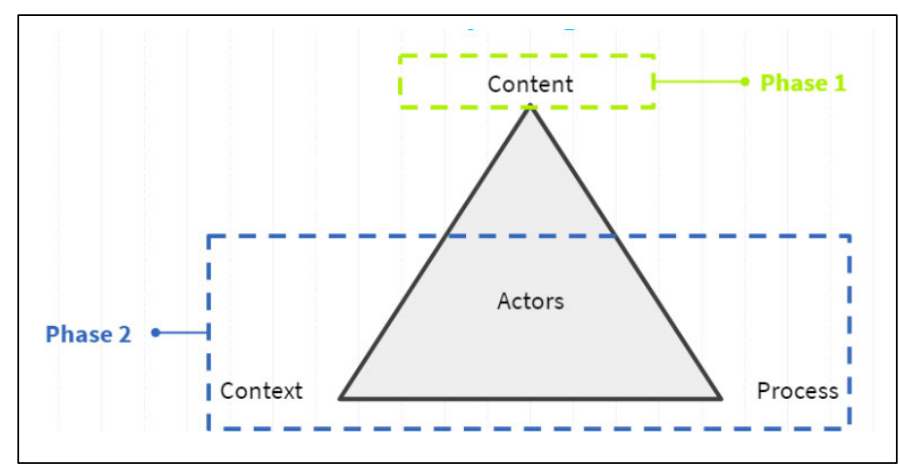


cluding but not limited to agency structures, resources, and values. The third HPT component is process, or how the policy works, such as style of decision-making, interventions, and evaluation. Within the HPT are the actors, the stakeholders who identify problems and shape decisions (Walt \& Gilson, 1994).

To address all aspects of the HPT, we examined content via a quantitative analysis of current legislation and assessed context, process, and actors through semistructured interviews with individuals involved with soil health legislation.

\section{Legislation Collection}

Legislation library databases from all 50 U.S. state government websites were used to identify current state soil health legislation. Legislation libraries were searched for key words - soil health, healthy soil, regenerative agriculture, and carbon farming from 2000-2019. Text copies were subsequently obtained from legislative libraries. The search identified 24 bills, including both introduced and enacted, from 15 states. From this pool, a purposive sampling method was utilized to include bills which met a set of pre-determined criteria (Palinkas et al., 2015). Any bills from the 2019-2020 legislative session that were proposed before February 2019 were included in analysis. Bills were excluded if soil health was merely mentioned but was not an aspect of legislation interventions. Amendments and concurrent resolutions without related soil health interventions were also excluded. Of the original 24 bills, 12 bills from 11 states were analyzed.

\section{Legislation Analysis}

A codebook was developed to ensure consistent bill content analysis. To assess both the breadth in which individual bills addressed soil health, as well as to compare between bills, our codebook was constructed using ontological categories from the accepted definition of soil health commonly recognized in scientific literature: biodiversity, bioproductivity, air quality, water quality, animal health, soil organic carbon (SOC), and public health (Bennett et al., 2010; Larkin, 2015; Moebius-Clune et al., 2016). Soil health definitions themselves were also coded to compare and contrast the characterization and extent of definitions within the bills.
Two codes for influencers of soil health determinants (land management practices and climate change) were included based on the emphasis found during literature review. To better understand the potential impacts of legislation, bills were coded for proposed interventions, outcome evaluation methods, and financing. Codes from each bill were recorded in Microsoft Excel.

Determinant codes (Table 1) from all bills were compiled and the number of total determinant codes counted. Codes from each determinant were divided by the number of total codes to find the proportion of codes for each determinant by bill and across bills. Additionally, the diversity of codes within each bill was compared across bills.

\section{Interview Recruitment, Collection, and Analysis}

An interview script (see the Appendix) was created to address the remaining three aspects of the HPT: context, process, and actors. All questions were submitted to and approved by the University of Washington Institutional Review Board (IRB). To gain a better understanding of soil health legislation context, process, and actors, we recruited individuals involved with the creation, proposal, or implementation of the bills and laws analyzed in this study. Potential interview participants were identified through a state soil health legislation Google group and the Soil Health Institute policy resources

Table 1. Summary of Legislation Codebook Categories and Codes

\begin{tabular}{ll}
\hline Category & Code \\
\hline Terms & Soil Health Definition \\
\hline Determinants & Biodiversity \\
& Bioproductivity \\
& Air quality \\
& Water quality \\
& Animal health \\
& Carbon sequestration \\
& Public health \\
\hline Influencers & Land management \\
& Climate Change \\
\hline Interventions & Policy actions or interventions \\
& Evaluation \\
& Finances \\
\hline
\end{tabular}


Table 2. Summary of Interview Codebook Categories and Codes

\begin{tabular}{ll}
\hline Category & Code \\
\hline Context & Motivations \\
& Vision/goals \\
& Target audience \\
& Self-reported soil health definition \\
& Perspective on increased proposal of legislation \\
& Factors linking soil health and public health \\
& Gaps or barriers to linking soil health and public health \\
\hline Process & Evaluation \\
& Challenges and barriers to bill adoption \\
& Challenges and barriers to law implementation \\
& Rationale \\
& Facilitators/enablers \\
\hline Actors & Key partners in creation \\
& Intervention stakeholders \\
& Connected programs \\
\hline
\end{tabular}

names have been changed for Interviewees $1-10$ to maintain confidentiality, but participant affiliation (e.g., farmer, community volunteer) and general geographic location are shown after quotes in order to provide context to interviewee perspectives.

Interviews were conducted with individuals involved in soil health legislation from 10 of the 11 states with legislation included in the quantitative analysis. Iowa was not included due to nonresponse. Professional affiliations of interviewees varied (Table 3) and included government agency program coordinators, policy directors at environmental nonprofit organizations, volunteer citizens, a farmer, an organic business consultant, and an environmental attorney. Some volunteer citizens were associated with a community climate action group while others worked for agricultural or environmental programs but had dedicated their personal time to support the legislation. Interviewees were involved with the legislative process in different ways, such as managing enacted soil health programs, drafting legislation, and testifying for soil health legislation before state congresses. Several themes emerged from these interviews, which are organized in the Results section within the Health Policy Triangle framework categories of context, process, and actors.

\section{Limitations of Methods}

A key strength of this research is its incorporation of both policy analysis and qualitative interviews, including participation of interviewees from diverse

\section{Table 3. Distribution of SHP Affiliations}

\begin{tabular}{lc}
\hline SHP Affiliation & $\begin{array}{c}\text { Number of } \\
\text { Interviewees }\end{array}$ \\
\hline Volunteer citizens & 3 \\
\hline Environmental non-profit policy advisor & 2 \\
\hline Government agency employee & 2 \\
\hline Farmer & 1 \\
\hline Organic business consultant & 1 \\
\hline Environmental attorney & 1 \\
\hline
\end{tabular}


backgrounds ranging from governmental agency employees to organic farming. Nevertheless, policy analysis involves several inherent limitations, especially when comparing legislation between U.S. states, because each state has different legislative requirements, such as bill length and structure. To address this, we calculated proportions to normalize the appearance of code data, and thereby offset any effect of varying lengths of bills. To create the proportions, the total number of bill codes was used as a denominator, and bills were also compared by using each bill as its own denominator. In addition, for our interviews only one individual involved in soil health legislation was interviewed from each state, providing singular insight for contextual factors that may not fully reflect the viewpoint of other policy constituents involved. While interviews spanned a variety of individuals, only one farmer responded to interview recruitment. This may be due to the nature of agricultural policy proposal efforts, in which nonprofit and community groups advocate for associated farmer constituents, yet presents the potential for bias. Similarly, we are missing key state government representative perspectives because this research was conducted during the legislative cycle and no representatives responded to interview requests. Finally, perspectives on limitations and facilitators to collaboration between soil health and public health disciplines are also one-sided, as no public health professionals who were involved in soil health legislation proposal, creation, enactment, or implementation of bills and laws analyzed for this study were able to be identified for interviews.

\section{Results}

Legislation Status

Three states-California, Hawaii, and Maryland—had passed soil health legislation prior to the 2019 legislative session. California was the first to enact soil health legislation, in 2016; Maryland and Hawaii followed in 2017 (see the map in Figure 2).

Nine soil health bills were proposed during the 2019 legislative session: bills from Washington, New Mexico, Iowa, Illinois, New York, Vermont, Massachusetts, and two from Nebraska. A table of the bills with legislative number and status as of July 10, 2019, is in Table 4.

\section{Legislation Analysis: Content}

\section{Defining soil health}

While the nine bills all mention soil health, only legislation from California, Massachusetts, Maryland, New Mexico, and Illinois define the term, with little diversity, most using a variation of the California definition:

"Healthy soils" means soils that enhance their continuing capacity to function as a biological system, increase soil organic matter, improve soil structure and water- and nutrient-holding capacity, and result in net long-term greenhouse gas benefits. (Agricultural lands: greenhouse gases: Healthy Soil Program SB-1350, 2016, Sec. 3)

\section{Figure 2. Map of States with Proposed or Passed Soil Health Legislation as of February 2019}

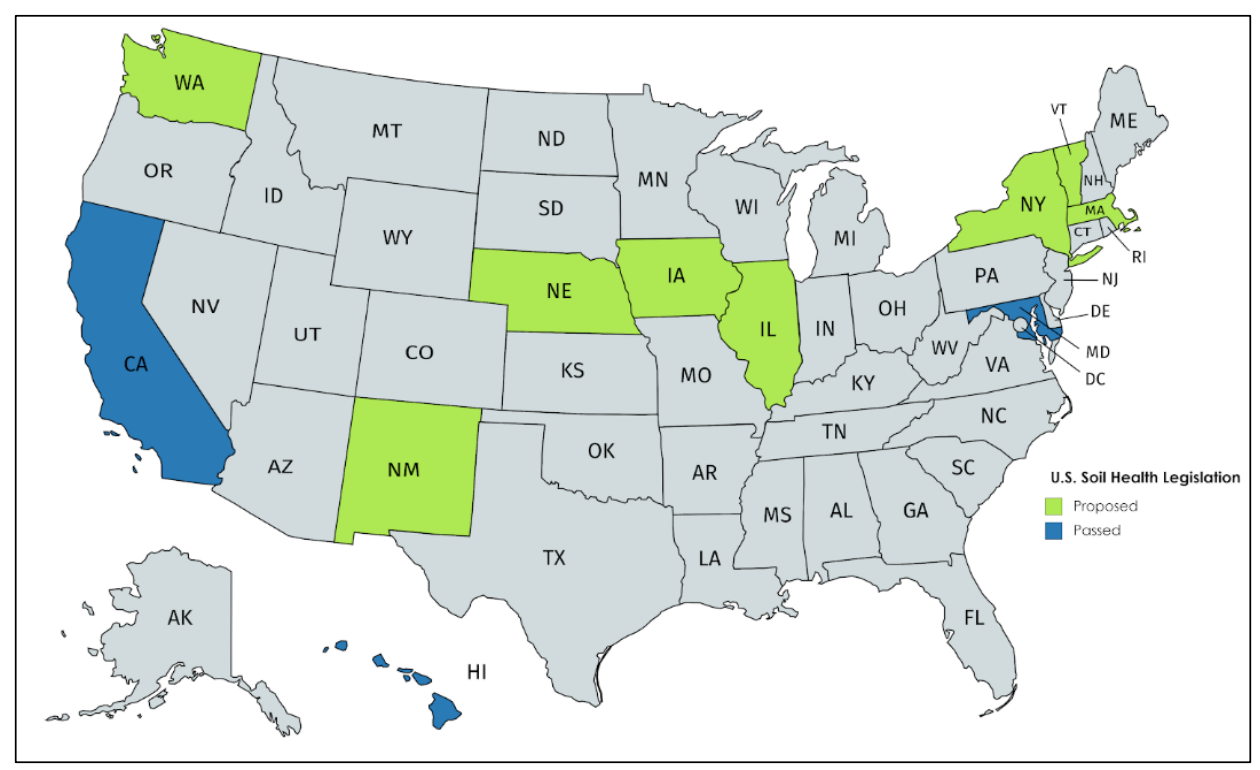


Journal of Agriculture, Food Systems, and Community Development

ISSN: 2152-0801 online

https:// foodsystemsjournal.org

Table 4. Status of Legislation as of July 2019

\begin{tabular}{|c|c|c|c|c|}
\hline State & Bill & Status as of February 2019 & Status as of July 2019 & Year/Session \\
\hline $\mathrm{CA}$ & SB 1350 & Passed & Passed & 2016 \\
\hline MD & H.373 & Passed & Passed & 2017 \\
\hline $\mathrm{HI}$ & Act 15 & Passed & Passed & 2018 \\
\hline MA & S438 & In committee & In joint committee & 2019 \\
\hline VT & H.903 & In committee & Incorporated into H.525 and passed & 2019 \\
\hline NY & A2781 & In committee & In committee & 2019 \\
\hline NM & S.218 & In committee & Passed & 2019 \\
\hline IL & $\mathrm{S} 1980 / \mathrm{H} 2737$ & In committee & Passed & 2019 \\
\hline IA & $\mathrm{H} 102$ & In committee & In committee & 2019 \\
\hline \multirow{2}{*}{ NE } & LB243 & In committee & Passed & 2019 \\
\hline & LB729 & In committee & In committee & 2019 \\
\hline WA & S5947/H2095 & In committee & Passed senate, tabled in house committee & 2019 \\
\hline
\end{tabular}

The exception is Illinois, whose bill adds a reference to soil's capacity to "sustain plants, animals, and humans" as a characteristic of soil health (An Act Concerning Local Government, 2020, Sec. 5, 405/3.23).

Some states chose to use a different overarching term in place of soil health. For instance, the definition of regenerative agriculture in Vermont's bill closely resembles soil health definitions found in other state legislation:

Regenerative agriculture describes farming and grazing practices that, among other benefits, reverse climate change by rebuilding organic matter in soil and restoring degraded soil biodiversity, resulting in carbon drawdown, improved retention of water in soil, and improved water quality. (An Act Relating to Regenerative Farming, 2018, p. 2)

New York and Washington used the term carbon farming, which represents a more targeted approach focusing primarily on carbon sequestration. New York defines carbon farming as the "implementation of a land management strategy for the purpose of reducing, sequestering, and mitigating greenhouse gas emissions on land used in support of a farm operation" (Carbon Farming Act, 2017, Sec.1, Subdiv. 5). Although all bills discuss soil health, the difference in terms demonstrates varia- tion in the broader legislative vision, goals, and contexts.

\section{Determinants}

Overall, 142 determinant codes were identified among the 12 bills. Carbon sequestration was cited the most often, accounting for 45 of the 142 codes (31\%). Water quality followed with 36 mentions $(25 \%)$ but was mentioned more widely $(11 / 12$ bills) than carbon sequestration (10/12 bills). Biodiversity and bioproductivity represented a similar percent of determinant codes $12 \%$ and $13 \%$ respectively) and were also mentioned in a similar number of bills $(9 / 12$ and 8/12). More than half of the bills referenced public health $(7 / 12)$, but public health was mentioned only a total of 11 times, contributing to $8 \%$ of determinant codes. Animal health appeared slightly less than public health, accounting for 10 of the 142 determinant codes $(7 \%)$ and mentioned in $5 / 12$ bills. Air quality accounted for both the lowest proportion of total determinant codes, with 5/142 codes (4\%), and the least common determinant with mention in only two bills (Figure 3).

Figure 4 illustrates the relative composition of each bill by determinant code. No bill addressed all even soil health determinants as outlined in the legislation analysis methods. The average number of determinants mentioned was 4.3. The California, Illinois, and Nebraska bills included the highest 
diversity of soil health determinants with six of the seven determinants cited, followed by New Mexico (5/7). Washington's bill included the least variety of soil health determinants, citing only carbon sequestration $(1 / 7)$.

\section{Influencers and interventions}

Land management practices were the primary influencer and focus of legislative interventions, mentioned in 11 of 12 bills. Only seven of the 11 bills cited specific land management practices, cataloged in Table 5. The most commonly cited land management practices included cover cropping and no-till or conservation tillage. Main legislative interventions (Table 6) include financial and technical assistance programs offering incentive-based grants, equipment loans, and education. Five of the 12 bills included methods of intervention evaluation. Only four bills (Hawaii, New Mexico, Massachusetts, and Vermont) discuss funding sources.

\section{Legislative Context}

As Walt and Gilson (1994)

discussed, context is the background information about the environment and situational factors that influence policy development. Many contextual themes emerged during our analysis: (1) the desire to normalize and mainstream soil health, (2) climate change motivating bill proposals, (3) improved bill support due to heightened visibility of research and more frequent extreme weather events, (4) understanding of soil as a living ecosystem, and (5) connections between soil health and public health. Each of these is further discussed below, with illustrative quotes from interviewees.

\section{Figure 3. Which Soil Health Determinants were Mentioned the Most Often in Soil Health Legislation by Illustrating the Percent of Each Soil Determinant Over Total Codes from All Bills}

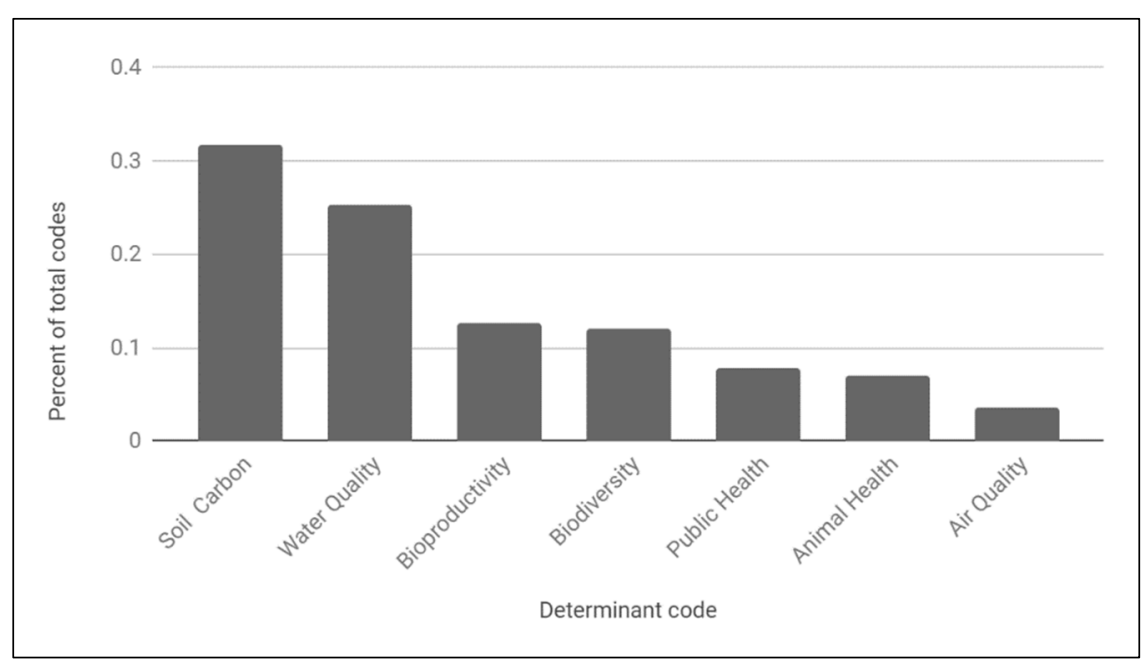

Figure 4. Percent of Soil Health Determinant Codes Mentioned by State Each color represents a different soil health determinant. The more colors per bar demonstrates a higher diversity of determinants in a bill.

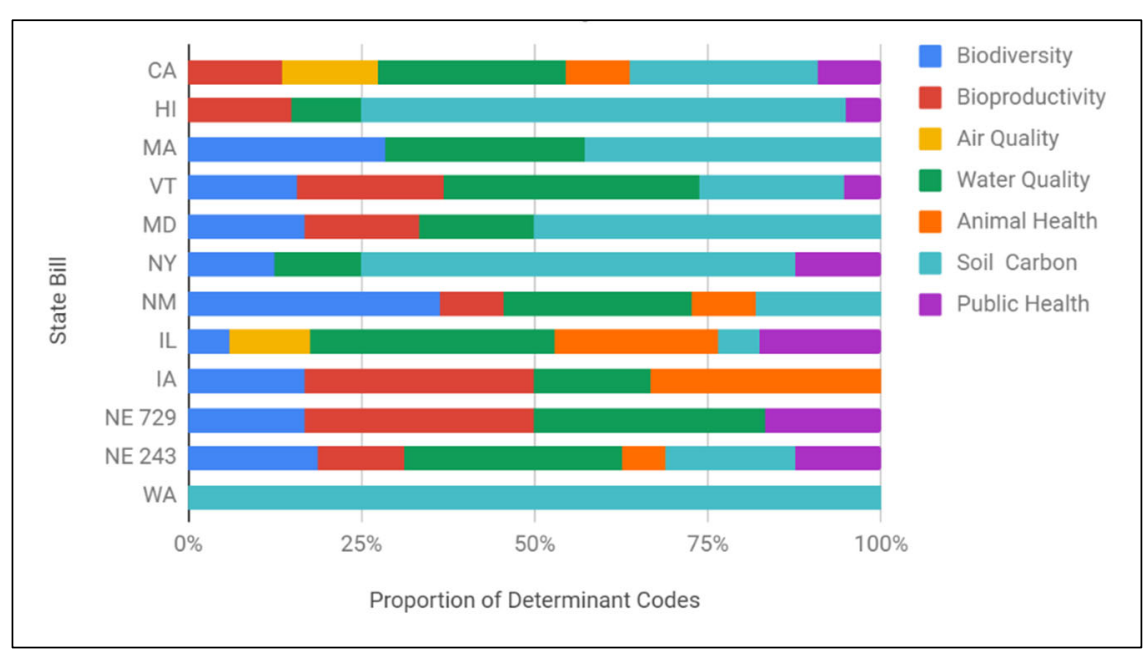

Normalizing and mainstreaming soil bealth

A general mission for legislative bills, as described by interviewees, was to increase the visibility of the concept of soil health to make soil health practices more normalized and mainstreamed. Interviewees noted that while many important land management practices have been around for hundreds of years, they have yet to be thoroughly articulated in policy. While gathering research for writing legislation, an interviewee observed very little adoption of soil health practices, such as no-till or cover cropping, by farm and land managers. Many entities were 
Table 5. Land Management Practices Cited Within Bills, by Number of Bills That Refer to a Specific Practice

\begin{tabular}{ll} 
Land Management Practice & $\begin{array}{c}\text { Number of bills that } \\
\text { refer to practice }\end{array}$ \\
\hline Cover cropping & 7 \\
\hline No-till/low-till & 4 \\
\hline Rotational/planned grazing & 4 \\
\hline Agroforestry & 2 \\
\hline Compost/manure application & 2 \\
\hline Integrated crop-livestock systems & 2 \\
\hline Planting perennials & 2 \\
\hline Reduce chemical application (fertiliz- & 2 \\
ers, insecticides, and herbicides) & 1 \\
\hline Biochar application & 1 \\
\hline Planting hedgerows & 1 \\
\hline Planting native vegetation & 1 \\
\hline Mulching & 1 \\
\hline Multicropping & 1 \\
\hline Soil microbial inoculation &
\end{tabular}

Table 6. Distribution of Legislative Interventions by State

\begin{tabular}{ll}
\hline Legislative Intervention & States \\
\hline Task force creation & NE 243, HI \\
\hline $\begin{array}{l}\text { Technical and financial } \\
\text { assistance program }\end{array}$ & CA, MD, NM, WA, VT, MA \\
\hline Financial assistance only & NE 729 \\
\hline Tax credit & NY \\
\hline $\begin{array}{l}\text { Expanding scope of Soil and } \\
\text { Water Conservation Districts }\end{array}$ & IL \\
\hline
\end{tabular}

promoting soil health as a concept, but the efforts had yet to be translated into increased action.

We needed to figure out a way to promote wider use of these practices among farmers and land managers. We thought we needed to put a big spotlight on these practices through the creation of a healthy soils initiative and the formation of a task force. (Midwest volunteer citizen)

In a related comment, one interviewee underscored the need to emphasize more the history of soil degradation in the U.S., and believed that creating legislation was one way to increase the visibility of the issue:

We aren't working in a vacuum; we are working with other very forward moving leaders who are already doing a lot around the country. What we want to achieve is to spread this good work and make it mainstream. So it becomes the norm and not the exception.

(Southwest volunteer citizen)

Another interviewee noted that many soil health efforts were directed solely on preserving topsoil, and saw a need for broadening perception to include preserving an environment sustainable for crops and animal production over time: "We want to get some of these practices to be more commonplace and not make it something wacky that one of your neighbors is doing that you don't understand." This interviewee also noted that to accomplish this goal means educating not only farmers, but lawmakers as well.

Three other interviewees echoed these sentiments, adding that normalizing ideas among legislators is the first step to bringing about change. According to them, lawmakers often are unaware of healthy soil concepts prior to bill proposals:

When you take just 15 minutes to explain how soils can store carbon from the atmosphere and how that helps with life within the soil, [and] therefore plants and animals, people get it. People understand. It's just trying to make people see how wide the reach of soil health is. That it's not just one metric like soil carbon but also biodiversity, water, animal and human health. It's a very large system to explain.

(Northeast farmer)

\section{Climate change mitigation}

The capacity for soils to sequester atmospheric carbon as a potential mitigator of climate change was cited as a motivating factor by eight of the 10 interviewees. They believe that climate change policy has historically focused on transportation and energy systems, but that only recently has agriculture been recognized as a player in climate change solu- 
tion. One interviewee perceived an "upward trend in recognizing how soils are an untapped climate change mitigator. I think as climate change has become more dire, people are looking for any and all options." Another interviewee stated that the impacts of climate change are compelling legislators to start to "think about how to make farms more resilient to the changing climate down the road."

In some states, like California and Washington, passage of climate action plans has motivated healthy soil legislation as a strategy to meet emission goals. States with more conservative constituents used the healthy soil issue to address climate change indirectly.

We realized the chance of getting the climate action plan passed was limited, so we started to look at alternatives. We found that healthy soil has a lot of benefits to the agricultural community, but also had benefits beyond in terms of its ability to sequester carbon and reduce greenhouse gas alternatives. So, we decided to make a healthy soils bill as a plan B to the carbon action plan. (Midwest volunteer citizen)

For other interviewees, lack of climate change action at the federal level served as a powerful motivator. One interviewee believed the increase in proposals for soil health legislation over the last few years is a consequence of people being "tired of waiting for things to be done by the national government, so they are starting to find ways to protect nature themselves through state action." Another noted that frustration with the absence of federal efforts has likely "encouraged some states to get their act in gear."

While climate change was a major and primary motivator, one interviewee pointed out that the other benefits of improving soil health trump those of carbon sequestration:

My argument is that if someone waved a magic wand and there were no more problems with carbon, we were essentially at pre-industrial levels of greenhouse gases, we would still have only 60 years of topsoil left. We would still have all these flooding problems because of soil compaction. We would still have water quality issues because of chemical amendments. If we address all these other issues, carbon [sequestration] is a significant bonus. (Northeast volunteer citizen)

The perfect storm: Research and weather influencing policy When discussing the recent increase in soil health legislation, interviewees suggested two chief explanations for increase in farmer support for soil health policies: recent research and more frequent extreme weather events. In 2012, the Natural Resource Conservation Service of the U.S. Department of Agriculture started a soil health campaign, "Unlocking the Secrets of Soil Health" (NRCS, 2018). Mentioned by several interviewees, the initiative has helped spread awareness of soil health through educational programming. Interviewees also reported increased discussion of soil health in local news publications, university extension programs, and community nonprofits.

There has been enough research, successful case studies, and examples of farmers adopting things like no-till and cover crops that people are starting to recognize the benefits to their bottom line. Also, in terms of yield, soil retention, and water retention. (West Coast nonprofit policy advisor)

Soil health has almost become a buzz word in agricultural conservation with the explosion of scientific knowledge in the last few years. Historically, soil health was very much considered by farmers. I think a rediscovery is occurring due to the increased support from the scientific community. (Northeast government agency employee)

In addition, an interviewee reported that many farmers and ranchers are starting to feel substantial pressure from extreme weather such as droughts and flooding, which have become more frequent in the last few decades (Mallakpour \& Villarini, 2015; Peters, Iverson, \& Matthews, 2014). One interviewee, whose state has recently experienced multiple severe floods, observed that farmers who do not believe in climate change are starting to notice that "things are changing" and the risks those 
changes pose to agricultural production. Another interviewee believed the perceived increase in extreme weather events improved issue visibility to create the "perfect storm" for legislation proposal: "The latest changes to storm water and drought have elevated the awareness about the need to address soil issues. In a way, the ground was ready for legislation to take hold."

Soil as a living ecosystem

When asked to define soil health, interviewees provided a resoundingly unified answer: soils are living ecosystems. While interviewees cited more specific soil health characteristics, such as those defined in Doran, Sarrantonio, and Liebig's definition of soil health (e.g., biodiversity, water system health, and plant and animal health), many stated soil can be thought of simply as an ecosystem. One interviewee said, "soil is a living organism with worms, fungi, insects, and organic matter. We are just trying to increase the naturally occurring nutrients and minerals to make a perfect medium for growing plants and crops." Another interviewee agreed, stating healthy soil is soil that is "full of life." Some interviewees described the soil ecosystem as analogous to the human body, relating the different soil functions to organ systems.

When we think of health we think of systems function and lots of different services. So I think there is a natural metaphor with the body. Soil health means soils that are biologically functioning and providing the ecological services that they would provide in their natural state. (West Coast nonprofit policy advisor)

Soil is its whole own ecosystem. I like to think of soil as earth's digestive system. Just like your body takes food and breaks it down into something your body can use for energy, the earth is taking inputs and breaking them down into products plants can use, and then animals can use. (Northeast farmer)

One interviewee compared soil to the human gut, drawing specific parallels between soil and gut microbiota. Similarities have been described be- tween the systematic functions of both microbiotas, in terms of immunological function and metabolic capacity (Ramírez-Puebla et al., 2013). The interviewee believed that not acknowledging these connections is based on limitations in people's imagination and perception of soil: "we cannot see what we kill in the soil every day, so it escapes our compassion."

\section{Connecting soil health and public health}

Interviewees not only reported analogies between soil and the human body, but also discussed ways that soil health directly impacts public health. Seven of the 12 bills analyzed mentioned soil health's connections to human health through improving water quality, increasing crop yields, and improving community health. Interviewees discussed similar factors but emphasized two: soil nutrient level and chemical pollutants.

Five of the nine interviewees reported soil nutrient level as a main connection between soil and public health due to soil's capacity to transfer nutrients, specifically micronutrients, to crops.

I think one of the things that comes to mind immediately is nutrient density of foods. Those are very closely related. A healthy soil is integral in increasing nutrient density and nutrient density is critical for healthy food. Which leads to a healthy population. (West Coast organic business consultant)

Specifically, interviewees reported conventional agriculture as a culprit in soil nutrient degradation, responsible for reduced food nutrient density. One interviewee stated that concentrations of certain micronutrients in produce had drastically decreased or gone "completely missing" over the last 50 years. Another interviewee agreed:

The old saying that an apple a day keeps the doctor away is no longer true; now it takes something like 15 apples to equal the nutritional equivalent of an apple from the 1930s when that saying gained popularity. We've changed nature to the point where it looks the same, but it is fundamentally different. (Northeast farmer) 
One interviewee claimed that an inverse association exists: the types of crops that fuel an unhealthy diet are related to agricultural practices that erode soil health. Significant amounts of herbicides and chemical fertilizers are often used for commodity crops such as corn and soybeans to maximize yields from even degraded soils. These crops are often used in more highly processed food products.

We know those foods in the Western diet are not particularly healthy, which leads to multiple issues. And we know that the desire to produce as much of those crops as cheaply as possible is what is leading to a significant negative impact on soil health. So, it flows both ways. (West Coast organic business consultant)

Two interviewees expanded this connection, stating that healthy soils are crucial in maintaining future crop yields as climate change continues to put stress on the food system:

Especially in the next couple of decades soil health is going to become increasingly crucial to overall food system resiliency. Events that capture this are droughts and flooding. NRCS says that a $1 \%$ increase in soil organic matter results in soil having the capacity to hold 2500 more gallons of water per acre. That's a drought and flood resilience solution, but also erosion control. So that will be really important for food security in the future. (West Coast nonprofit policy advisor)

In addition to improving crop nutrient density, interviewees also associated healthy soil with reduced pollutants which have negative effects on public health.

If you can reduce the amount of chemicals and fertilizers you put on the soil, you are going to reduce the exposure that farmers have to things that have been scientifically proven to have carcinogens in them and produce cancer. (Midwest volunteer citizen)
One interviewee stated similar sentiments: "healthy soil practices pretty much exclude using harmful pesticides or chemical fertilizers, so you do create a healthier product." In addition to reduced chemicals, two interviewees discussed nitrate pollution of drinking water due to water running off agricultural lands into streams and rivers, and nitrates seeping into groundwater. One described how these benefits are paired with a reduction in "leaking of nitrogen in any direction. So, it would reduce volatilization of nitrogen into the air and leakage of nitrogen into waterways."

\section{Legislative Process}

The HPT framework describes process as how policies are developed implemented to bring about change (Walt \& Gilson, 1994). A crucial process theme that was identified in interviews was that discussing climate change posed either limitations or benefits to gaining support for bills during the bill proposal process. Interviewees brought up a variety of other process limitations, but they did not fall under one unifying theme. Reported limitations to evaluating policies was also identified as a process theme.

\section{The climate change divide}

For some states, addressing carbon sequestration and climate change in the text of the legislation reportedly facilitated bill support or passage. For other states, interviewees shared that discussing carbon and climate change in legislation presented a significant barrier to legislation proposal and passage: "if you mention climate change to the legislature, then $50 \%$ of them are already against what you are going to talk about." Another interviewee reported a similar response in their state:

Any program that mentions carbon is sort of toxic to begin with regardless of where the money flows. It seems to be a domino theory where [people believe] if you have a program that relies on cap and trade funds to incentivize agricultural practices that will add more momentum to the cap and trade carbon initiatives that could hurt farmers down the road by increasing the costs of diesel or what have you. (West Coast organic business consultant) 
The pushback comes not just from legislators, but from agricultural organizations as well, such as state Farm Bureaus.

[The Farm Bureau] did not want us to talk about carbon at all. So we ended up taking it out so that they would have our back going forward. There is a weird stigma with some of those words like carbon. Ultimately our organization believes climate change is a very real thing and that the conventional farming practices have contributed a lot in the way of our carbon loss and dead zones in the gulf. We believe this is all man's doing in the end. But organizations like the Farm Bureau aren't on board with admitting that yet. (Midwest nonprofit policy advisor)

The folks that seem to be the most opposed to the bill are the Farm Bureau and Dairy Federation. I still don't understand why they would be opposed to [the bill] since it is tax dollars going to farmers to upgrade pumps and put in equipment and such. So, I don't understand the rationale to their opposition, but it's politics so it doesn't always make sense. (West Coast organic business consultant)

Two interviewees believe that words such as climate and carbon have an innate political stigma because many farmers in rural America are very conservative and do not believe in climate change. Therefore, these words present a barrier for passing legislation.

The realities of being pragmatic in a legislative setting is that you need to not say things to keep bipartisan support. Everyone can agree that using a cover crop can reduce soil erosion and adds carbon to the soil. If we know that using a cover crop can increase soil health and therefore increase human health down the road, why even mention it in the first place if you risk losing support of the people you need to get the bill through legislature? (West Coast organic business consultant)

This experience differs from that of three in- terviewees who received bipartisan support for soil health legislation that included discussions of carbon sequestration and climate change. One reported their state Farm Bureau, Farmers Union, and American Farmland Trust co-sponsored the state's healthy soils bill: "This is one of those issues that is very bipartisan. The co-sponsors of the bill are essentially the same proportion of Republican and Democrat as the general legislature." Furthermore, another interviewee believed that soil health bills themselves could help bridge the climate change political divide:

One motivation of this bill was a broader political interest in trying to enlist rural communities, particularly farmers, into a climate change debate. This will perhaps reduce the urban/ rural divide that has become so pernicious in American politics. (Northeast environmental attorney)

\section{Farmer antipathy to government regulations}

Some interviewees reported other process limitations, including farmers' distrust of laws and desire to remain unregulated: "There are two big issues beyond climate change. One of them is that farmers don't want to be told how to farm and the other is farmer's fear of regulations." Another interviewee discussed similar limitations:

You also have a lot of people who are distrustful of laws, even if they agree with the tenants of the legislation. You have farmers who don't want to be told what to do or how to do it, even if they already agree or are already implementing that practice. (Northeast farmer)

One interviewee reported response to talking to agricultural groups about the soil health bill; many pushed back due to fear of losing member support if leadership promoted a law creating more regulations on land management:

I think a lot of people in leadership roles were supportive of our bill if you would get them into a place where nobody could hear what they were saying. But the members of these groups feel so strongly about these two points 
that [leadership] doesn't want to lose their jobs. (Midwest volunteer citizen)

Two interviewees noted that while most farmers have good intentions, telling farmers how to farm creates tension between farmers and policymakers. One interviewee suggested that this resistance to change could also stem from the financial incentives agribusinesses use to encourage farmers to continue current practices, as well as from farmers' desire to remain autonomous. In the experience of one interviewee, promoting certain land management practices in soil health bills can be interpreted by farmers as blaming current practices for environmental degradation, and therefore blaming the farmers:

No farmer goes out there thinking they are doing something bad or with the intention to poison the world. They think they are doing the right thing. So, if you set a value statement to a practice it inherently creates a reaction. (West Coast organic business consultant)

\section{Improving farmers' bottom line}

In addition to citing limitations to soil health legislation adoption or implementation, interviewees shared factors that facilitated bill proposal or passage. A commonly cited facilitator to improving farmer buy-in was demonstrating a benefit to profits:

When we talk to farmers, we really emphasize that over time this could increase their bottom line, their profitability. Because they will produce crops with lower input costs because they won't use as high amounts of fertilizers. And you retain soil moisture and reduce erosion. In some cases, you even increase yields. Most importantly you are increasing your profit margin. Because the most important thing to this population is profit per acre. (Midwest volunteer citizen)

One interviewee believed that no agriculture program can be successful unless there is proven benefit to farmer profits: "if you can make an argument for how [you will improve their bottom line] like reducing use of fertilizer, pesticides, fuel, and irrigated water, you get their attention." Another interviewee believed that such facilitation is based on the structure of the agricultural system: "Like it or not the agricultural market is based solely on bottom lines. So, you have to try and reach [farmers] from an economic basis as well as an environmental lens." For one interviewee, focusing on profit as well as on farmer experience and farm families helps improve farmer buy-in for adopting new practices:

1) I'm having fun again, 2) I'm making more money, and 3) My kids are staying home and not going to the city. If you can make those three statements true about a practice, farmers will do it in droves. (West Coast organic business consultant)

\section{Evaluation plans}

Many interviewees reported that there were no formal evaluation plans to assess the effects of soil health legislation in their states. For some states still in the process of passing a bill, evaluation is set to come after the bill is ratified. Different challenges were brought up in deciding future evaluation processes. One interviewee stated that the lack of a standardized method to assess soil health that has been endorsed by the scientific community means that states will have to create their own standards for measuring change. Two interviewees discussed how a time frame could be a limiting factor, as reportedly it can take 3-5 years to start perceiving changes in soil health metrics based on changes in land management practices.

The California interviewee reported the most robust evaluation of any of the interviewees. California's Healthy Soils Program has performed informal qualitative evaluations through focus groups and interviews with participating farmers and technical-assistance professionals who are helping farmers apply to the program. The Healthy Soils Program is also using a modeling program managed by USDA and Colorado State University, COMET-Farm, ${ }^{1}$ to estimate carbon sequestration

${ }^{1}$ https://comet-farm.com/ 
on participating farms. These data have yet to be formally evaluated, according to the California interviewee.

\section{Legislative Actors}

Actors - the individuals and group members responsible for policy making-make up the last factor of the HPT. Within the HPT model, actors are inside the triangle, illustrating that policy content, context, and process are influenced by the values of policy actors (Walt \& Gilson, 1994). Two actor themes emerged from interviews: the common key partners in bill proposal and implementation, and the untapped potential in partnering with public health entities for soil health policy.

\section{Common key partners}

Interviewees reported a large variety of significant partners instrumental in the proposal or passage of soil health legislation in their states. The most commonly cited partners were local Soil and Water Conservation Districts (SWCD), which are managed by the National Association of Conservation Districts, a national nonprofit association that supports land managers through grassroots advocacy and education (National Association of Conservation Districts, 2019). SWCDs were mentioned by seven of the nine interviewees as major partners in bill creation. In some cases, state SWCD employees provided interviewees with research to justify a bill or helped interviewees find other professionals to help write the bill or testify on its behalf. One interviewee described how SWCDs contributed to the creation of soil legislation in the state:

The [SWCD] branch director was a huge help because they are well steeped in the political game and we are beginners. So, she really took us under her wing. And their organization works with ranchers and farmers every year. That was really crucial. I don't think we could have done it without her and the help of those ranchers. (Southwest volunteer citizen)

While SWCDs were frequently mentioned partners in bill creation, the NRCS was mentioned by several interviewees as a partner in program implementation. Nebraska Bill LB243 creates a Soil Health Task Force, a member of which would be the state NRCS chair. The California interviewee claims the California Healthy Soils Program was created to be "supplemental to and unique from the NRCS conservation program." The Healthy Soils Program works with farmers who have already received grant funding through the program to continue to receive funding through NRCS. The New Mexico interviewee hopes that the proposed healthy soils program in the state could match grant funds provided by the NRCS to participating farmers.

Other interviewees mentioned unique key partners such as state universities, local climate initiatives, and tribal communities. Regional key partners also emerged, with interviewees from Massachusetts and Vermont reporting collaboration with Northeast Organic Farming Association and the climate organization Soil4Climate. Overall, all interviewees mentioned more than one key partner, often from governmental and nonprofit sectors, but none indicated collaboration with public health organizations.

\section{Partnering with public health organizations}

Many interviewees believe there is an opportunity to include public health organizations in conservation efforts, but multiple barriers to increasing collaboration were identified. Some interviewees perceived an education gap, with the connections between soil health and public health not well understood by either entity. An interviewee suggested that this knowledge gap can create tension and misunderstanding between the two fields, while another attributed low collaboration to limited scientific research:

I think it's an education thing. A lot of people who think about public health think about eliminating anything that is a threat to public health, but just because something exists doesn't mean it's $100 \%$ bad. So, some of the choices that are being made are based on black and white thinking. (Northeast volunteer citizen)

I think one reason is the limited research. 
Specifically, no definitive research has linked soil nutrients to plant nutrition. Everything should be done with a basis in science.

(Northeast government agency employee)

Other interviewees believe the disciplines of public health and natural resources conservation are siloed, so that there is too much distance for collaboration. An interviewee asserted that lack of precedence is a current barrier: “There don't seem to be a lot of institutions that are overlapping between the two areas. So just from an institutional capacity and social capital perspective that seems to be a barrier into getting more collaboration." Another interviewee believes that collaboration between disciplines will require a larger paradigm shift:

We are all so siloed. There is a huge disconnect between human health and the natural world. Health care is now what you can take as a pill, not what you are eating. Soil is a major support system for humans, and I think that is very overlooked. (Northeast farmer)

An interviewee has started to observe positive changes, however, especially in the issue of air quality:

One of the things that we work with a lot is air pollution and public health professionals are already very involved on that front. There are obvious ties between breathing bad air and health. I think nutrient loss and soil health has not received as much attention yet, but as we continue to talk about it there will be more space to see how these practices affect communities around the country. (Midwest nonprofit policy advisor)

\section{Discussion}

Through policy analysis and interviews, we assessed the content of U.S. state soil health legislation and the context, process, and actors involved in bill proposal and implementation. Proposals of state soil health legislation has grown from two states prior to 2016 to more than 20 proposals in the last four years. Of the legislation analyzed in this project, nine bills were proposed in the 2019 legislative cycle. Bill content focused mainly on soil carbon sequestration and water quality, with minimal reference to public health. Interviews illuminated context themes: desire to normalize soil health practices, influence of climate change, appreciation for soil as a living ecosystem, and the need to better understand links between soil nutrient levels, soil health, and public health. Themes that emerged about the legislative process included climate change as both limiting and facilitating passage, farmers' dislike of regulations as a barrier to policy support, and the benefit of focusing on farmer profit margins to increase policy support. The most cited legislative actors were Soil and Water Conservation Districts and the NRCS, but interviewees recognized opportunities for collaboration with public health organizations in the future. To our knowledge, no prior studies have aggregated data on soil health legislation content, process, context, and actors. Nor has prior research assessed the extent to which public health is addressed in soil health legislation. Therefore, these findings provide a novel perspective.

As our study illustrates, despite well-established evidence connecting soil health to public health, more intentional inclusion of public health in recent legislation has remained minimal. This could be attributed to the lack of definitive research linking soil health and crop nutrient density, which would make a clear connection to the quality of food (Marles, 2017). A structural limitation also exists wherein policies for agriculture and policies for public health are handled in separate congressional committees, reducing ability for a multidisciplinary approach. Additionally, federal legislation often provides impetus for state legislation, and currently there are no federal policy examples linking agricultural soil management and public health.

As recognized by interviewees, opportunities for multidisciplinary collaborations are needed to better link public health with the agricultural and food system. Examples of multidisciplinary approaches do exist. For example, the One Health approach has gained traction over the last decade as a "collaborative, multisectoral, and transdisciplinary approach—working at local, regional, 
national, and global levels - with the goal of achieving optimal health outcomes recognizing the interconnection between people, animals, plants, and their shared environment" (Centers for Disease Control and Prevention, 2018, para. 1). Federally funded, in part through the Center for Disease Control, these initiatives involve a collaboration between farmers, researchers, and public health officials to address the spread of contagious diseases from animals to humans (CDC, 2018). Currently, this approach is being applied to zoonotic diseases and food safety in relation to the poultry and livestock industries, but it was not designed for this exclusively. Current One Health efforts understate upstream environmental solutions to public health threats, such as healthy soil's role in mitigating disease spread, supporting safe drinking water, and protecting the human food supply (Barrett \& Bouley, 2015). For example, the One Health approach could be applied to sustainable grazing initiatives, as a way to improve soil carbon sequestration to mitigate climate change and to reduce pathogen contamination through runoff to drinking water or recreational water sources. Expanding the focus of One Health to include soil health may be one way for policymakers to surpass current barriers limiting multidisciplinary approaches. Another multidisciplinary approach may be for actors from livestock, water, and public health sectors to collaborate on interdependent issues for mutual benefit, such as addressing nitrate, phosphorus, and heavy metal groundwater contamination from livestock production.

In addition, opportunities also exist to expand the current climate change focus in soil health legislation to include public health, and thus broaden support for soil health. For example, interviewees cited the benefit of emphasizing profit margins as a way to increase farmer support; it is possible farmer buy-in could also be achieved by bridging the gap between climate change and dietary patterns or by illustrating the productivity — and thus profitability-gains due to improved soil health. To elaborate, there has been a growing emphasis on dietary solutions to greenhouse gas emissions, such as using policy incentives to promote plant-based diets and reduce meat consumption (EAT-Lancet
Commission, 2019; Smith et al., 2019). These dietary patterns have been linked to both reduced fossil fuel output and reduced risk of chronic diseases such as cardiovascular disease and diabetes (Boeing et al., 2012; Smith et al., 2019). While this shift in eating patterns yields both environmental and public health benefits, it would lead to an even greater importance for soil health, to protect the viability of croplands. As healthy soils have the known capacity to sequester atmospheric carbon, the question should not be what to eat to reduce greenhouse gases, but what to eat to support soil health. Promoting this connection between climate change, soil health, and public health may benefit state soil health legislation aiming to promote sustainable land management practices. Recent findings that agricultural practices that build soil health prove more profitable without sacrificing productivity are starting to incentivize adopting such methods (LeCanne \& Lundgren, 2018; Montgomery, 2017). If consumers begin to purchase more food from producers using sustainable soil management practices, this will further increase farmers' bottom lines and encourage other producers to adopt similar practices.

Moreover, acting on opportunities to include public health in soil health legislation is becoming increasingly important as the momentum of state legislation proposal continues to strengthen. During this project, three of the analyzed bills were ratified into law, including NE LB243, IL HB2737, and NM HB204. The VT bill was incorporated into a larger act "relating to miscellaneous agricultural subjects" and was passed in the 2019 session. VT passed a second bill regarding soil health, VT S.160, which was proposed after the inclusion window of this research (VT S.160). According to the Healthy Soils Google Group, soil health legislation has now been submitted in Florida, Iowa, New Hampshire, Washington, and Massachusetts; legislative efforts in 2020 expanded to more states, including Missouri, Ohio, Pennsylvania, and Wisconsin (Soil Health Google Group, private communication, 2020).

\section{Recommendations}

While proposal and passage of soil health legislation in state legislatures has increased in recent 
years, inclusion of soil health and public health linkages remains minimal. Therefore, soil health policymakers have an opportunity to broaden the scope of new policies by adding or expanding educational interventions to improve producer and consumer knowledge of the connections between soil and public health. Many of our interviewees suggested legislation aimed at creating soil health task forces should consider including public health experts. Public health metrics, such as reducing concentrations of agricultural pesticides and heavy metals in water supplies, could be added to soil health assessments. Soil health legislation providing research grants could allocate funds specifically to investigate soil and public health connections.

State legislative policies do not occur in isolation. If current state-based efforts can be used to amplify attention to soil and public health connections, this may provide impetus for similar inclusion in federal policies. As population growth and climate change increase stress on agricultural soils, broadening the scope of soil health legislation to include public health could be a means of mitigating future threats to both public health and soil ecosystem services.

\section{References}

Agricultural lands: greenhouse gases: Healthy Soil Program, SB-1350. (2016). Agricultural lands: greenhouse gases: Healthy Soil Program SB-1350. Sacramento, CA: California Legislative Information. https://leginfo.legislature.ca.gov/faces/billNavClient.xhtml?bill id =201520160SB1350

Agriculture Improvement Act of 2018, Pub. L. 115-134. (2018). Agriculture Improvement Act of 2018, Pub. L. 115-134, 7 U.S.C. 9001, $115^{\text {th }}$ Congress. Washington, DC: Government Printing Office. https://www.govinfo.gov/link/plaw/115/public/334?link-type=pdf

Amundson, R., Berhe, A. A., Hopmans, J. W., Olson, C., Sztein, A. E., \& Sparks, D. L. (2015). Soil and human security in the 21 st century. Science, 348(6235), 1261071. https://doi.org/10.1126/science.1261071

An Act Concerning Local Government, P. Law 101-0484. (2020). An Act Concerning Local Government, P. Law 101-0484. Springfield: Illinois General Assembly. https://www.ilga.gov/legislation/publicacts/fulltext.asp?Name=101-0484

An Act Relating to Regenerative Farming, H.903. (2018). An Act Relating to Regenerative Farming, H.903. Bill/Resolution Text. Official. Montpelier, VT: Vermont General Assembly. https://legislature.vermont.gov/bill/status/2018/H.903

Antunes, P. M., Franken, P., Schwarz, D., Rillig, M. C., Cosme, M., Scott, M., \& Hart, M. M. (2012). Linking soil biodiversity and human health: Do arbuscular mycorrhizal fungi contribute to food nutrition? In D. H. Wall et al. (Eds.), Soil Ecology and Ecosystem Services (pp. 153-172). Oxford, UK \& New York: Oxford University Press. https://doi.org/10.1093/acprof:oso/9780199575923.001.0001

Barrett, M. A., \& Bouley, T. A. (2015). Need for enhanced environmental representation in the implementation of One Health. EcoHealth, 12(2), 212-219. https://doi.org/10.1007/s10393-014-0964-5

Basche, A. (2017). Turning soils into sponges: How farmers can fight floods and droughts [Research Report]. Cambridge, MA: Union of Concerned Scientists. https://www.jstor.org/stable/resrep17252

Bennett, L. T., Mele, P. M., Annett, S., \& Kasel, S. (2010). Examining links between soil management, soil health, and public benefits in agricultural landscapes: An Australian perspective. Agriculture, Ecosystems \& Environment, 139(1-2), 1-12. https://doi.org/10.1016/j.agee.2010.06.017

Boeing, H., Bechthold, A., Bub, A., Ellinger, S., Haller, D., Kroke, A., ... Watzl, B. (2012). Critical review: Vegetables and fruit in the prevention of chronic diseases. European Journal of Nutrition, 51(6), 637-663. https://doi.org/10.1007/s00394-012-0380-y

Brevik, E. C., \& Burgess, L. C. (2014). The influence of soils on human health. Nature Education Knowledge, $5(12), 1$. https://www.nature.com/scitable/knowledge/library/the-influence-of-soils-on-human-health-127878980/

Carbon Farming Act, A3281. (2017). Relates to establishing a carbon farming tax credit for farmers, Assembly Bill A3281. Albany, NY: New York State Senate. https://www.nysenate.gov/legislation/bills/2017/A3281

Centers for Disease Control and Prevention. (2018). One Health fact sheet. Atlanta, GA: CDC. https://www.cdc.gov/onehealth/basics/index.html 
Cumming, G. S., Buerkert, A., Hoffmann, E. M., Schlecht, E., Von Cramon-Taubadel, S., \& Tscharntke, T. (2014). Implications of agricultural transitions and urbanization for ecosystem services. Nature, 515(7525), 50-57. https://doi.org/10.1038/nature13945

Doran, J. W. , Sarrantonio, M., \& Liebig, M. A. (1996). Soil health and sustainability. In D. L. Sparks (Ed.), Advances in agronomy, Vol. 56 (pp. 1-54). Elsevier. http://dx.doi.org/10.1016/S0065-2113(08)60178-9

Doran, J. W., \& Zeiss, M. R. (2000). Soil health and sustainability: Managing the biotic component of soil quality. Applied Soil Ecology, 15(1), 3-11. https://doi.org/10.1016/S0929-1393(00)00067-6

Dumanski, J. (2015). Evolving concepts and opportunities in soil conservation. International Soil and Water Conservation Research, 3(1), 1-14. https://doi.org/10.1016/j.iswcr.2015.04.002

EAT-Lancet Commission. (2019). Summary report of the EAT-Lancet Commission: Healthy diets from sustainable food systems. Stockholm, Sweden: Stockholm Resilience Centre, EAT-Lancet Commission. http://eatforum.org/content/uploads/2019/07/EAT-Lancet Commission Summary Report.pdf

Environmental Quality Incentives Program (EQIP). (2016, May 12). Rules and regulations: Environmental Quality Incentives Program (EQIP). Federal Register, 81(92), 29471-29483. https://www.govinfo.gov/content/pkg/FR-2016-05-12/pdf/2016-10161.pdf

Fereday, J., \& Muir-Cochrane, E. (2006). Demonstrating rigor using thematic analysis : A hybrid approach of inductive and deductive coding and theme development. International Journal of Qualitative Methods, 5(1), 80-92. https://doi.org/10.1177/160940690600500107

Harrigan, K., \& Charney, A. (2018). Impact of 2018 Farm Bill provisions on soil health. Morrisville, NC: National Soil Institute, Washington, DC: National Sustainable Agriculture Coalition. https://sustainableagriculture.net/wpcontent/uploads/2019/09/FINAL-DIGITAL-Impact-of-2018-Farm-Bill-Provisions-on-Soil-Health.pdf

Keesstra, S. D., Geissen, V., Mosse, K., Piiranen, S., Scudiero, E., Leistra, M., \& van Schaik, L. (2012). Soil as a filter for groundwater quality. Current Opinion in Environmental Sustainability, 4(5), 507-516. https://doi.org/10.1016/i.cosust.2012.10.007

Lal, R. (2004). Soil carbon sequestration impacts on global climate change and food security. Science, 304(5677), 16231627. https://doi.org/10.1126/science.1097396

Larkin, R. P. (2015). Soil health paradigms and implications for disease management. Annual Review of Phytopathology, 53 , 199-221. https://doi.org/10.1146/annurev-phyto-080614-120357

LeCanne, C. E., \& J. G. Lundgren. (2018). Regenerative agriculture: Merging farming and natural resource conservation profitably. PeerJ: Life \& Environment, 6:e4428. https://doi.org/10.7717/peerj.4428

Mallakpour, I., \& Villarini, G. (2015). The changing nature of flooding across the central United States. Nature Climate Change, 5(3), 250-254. https://doi.org/10.1038/NCLIMATE2516

Marles, R. J. (2017). Mineral nutrient composition of vegetables, fruits and grains: The context of reports of apparent historical declines. Journal of Food Composition and Analysis, 56, 93-103. https://doi.org/10.1016/j.jfca.2016.11.012

Matson, P. A., Parton, W. J., Power, A. G., \& Swift, M. (1997). Agricultural intensification and ecosystem properties. Science, 277(5325), 504-509. https://doi.org/10.1126/science.277.5325.504

McHugh, M. L. (2012). Interrater reliability: The kappa statistic. Biochemia Medica, 22(3), 276-282. https://pubmed.ncbi.nlm.nih.gov/23092060/

Moebius-Clune, B. N., Moebius-Clune, D. J., Gugino, B. K., Idowu, O. J., Schindelbreck, R. R., Ristow, A. J., ... Abawi, G. S.. (2016). Comprehensive assessment of soil health-The Cornell framework. Ithaca, NY: Cornell University, School of Integrative Plant Science. http://www.css.cornell.edu/extension/soil-health/1concepts.pdf

Montgomery, D. R. (2017). Growing a revolution: Bringing our soil back to life. New York: W. W. Norton.

National Association of Conservation Districts. (2019). About NACD. Washington, DC: NACD. https://www.nacdnet.org/about-nacd/

National Soil Survey Center. (2015). Soil health literature summary. Effects of conservation practices on soil properties in areas of cropland. Lincoln, NE: U.S. Department of Agriculture, Natural Resources Conservation Service, National Soil Survey Center. https://www.nrcs.usda.gov/wps/PA NRCSConsumption/download?cid=stelprdb1257757\&ext=pdf 
Natural Resources Conservation Service. (2018). Soil health. Washington, DC: U.S. Department of Agriculture, NRCS. https://www.nrcs.usda.gov/wps/portal/nrcs/main/soils/health/

Natural Resources Conservation Service. (2020a). Conservation Stewardship Program. Washington, DC: U.S. Department of Agriculture, NRCS. https://www.nrcs.usda.gov/csp

Natural Resources Conservation Service. (2020b). Honoring 85 years of NRCS - A brief history.Washington, DC: U.S. Department of Agriculture, NRCS. http://www.nrcs.usda.gov/wps/portal/nrcs/detail/national/about/history/?cid=nrcs143 021392

Palinkas, L. A., Horwitz, S. M., Green, C. A., Wisdom, J. P., Duan, N., \& Hoagwood, K. (2015). Purposeful sampling for qualitative data collection and analysis in mixed method implementation research. Administration and Policy in Mental Health and Mental Health Services Research, 42(5), 533-544. https://doi.org/10.1007/s10488-013-0528-y

Peters, M. P., Iverson, L. R., \& Matthews, S. N. (2014). Spatio-temporal drought trends by forest type in the conterminous United States, 1960-2013. Boise, ID: U.S. Department of Agriculture, U.S. Forest Service. https://doi.org/10.2737/NRS-RMAP-7

Ramírez-Puebla, S. T., Servín-Garcidueñas, L. E., Jiménez-Marín, B., Bolaños, L. M., Rosenblueth, M., Martínez, J., ... Martínez-Romero, E. (2013). Gut and root microbiota commonalities. Applied and Environmental Microbiology, 79(1), 2-9. https://doi.org/10.1128/AEM.02553-12

Schmidt, M. W. I., Torn, M. S., Abiven, S., Dittmar, T., Guggenberger, G., Janssens, I. A., ... Trumbore, S. E. (2011). Persistence of soil organic matter as an ecosystem property. Nature, 478(7367), 49-56. https://doi.org/10.1038/nature10386

Smith, P., Nkem, J., Calvin, K., Campbell, D., Cherubini, F., Grassi, G., ... Taboada, M. A. (2019). Interlinkages between desertification, land degradation, food security, and greehouse gas fluxes: Synergies, trade-offs, and integrated response options. In Climate change and land: An IPCC special report on climate change, desertification, land degradation, sustainable land management, food security, and greenhouse gas fluxes in terrestrial ecosystems (Ch. 6). Geneva, Switzerland: Intergovernmental Panel on Climate Change. https://www.ipcc.ch/srccl/

Soil Health Institute. (2020). Soil health policy resources catalog. Morrisville, NC: Soil Health Institute. https://soilhealthinstitute.org/resources/catalog/

Tan, Z. X., Lal, R., \& Wiebe, K. D. (2005). Global soil nutrient depletion and yield reduction. Journal of Sustainable Agriculture, 26(1), 123-146. https://doi.org/10.1300/J064v26n01_10

Tilman, D., Balzer, C., Hill, J., \& Befort, B. L. (2011). Global food demand and the sustainable intensification of agriculture. Proceedings of the National Academy of Sciences of the United States of America, 108(50), 20260-20264. https://doi.org/10.1073/pnas.1116437108

Wall, D. H., Nielsen, U. N., \& Six, J. (2015). Soil biodiversity and human health. Nature, 528(7580), 69-76. https://doi.org/10.1038/nature15744

Walt, G., \& Gilson, L. (1994). Reforming the health sector in developing countries : The central role of policy analysis. Health Policy and Planning, 9(4), 353-370. https://doi.org/10.1093/heapol/9.4.353

Ward, M. H. (2009). Too much of a good thing? Nitrate from nitrogen fertilizers and cancer. Reviews on Environmental Health, 24(4), 357-363. https://doi.org/10.1515/reveh.2009.24.4.357 


\section{Appendix: Interview Script}

\section{Context Questions}

1. To begin, can you please state your name, position, and agency?

2. Can you please describe soil health in your own words?

Probe for:

- Factors that make up soil health.

- Difference between soil health and soil quality.

3. Why do you think is it important to define or characterize soil health?

Probe for:

- In your position, how is this definition used in practice?

- Why did your program/state choose these variables to categorize soil health?

- What led you to choose this definition of soil health?

4. In what ways have you been, or are you, involved with soil health legislation or policies?

5. Why is it important to you to have a policy around soil health?

Probe for:

- Beliefs and values relating to including soil health in conservation.

6. Do you believe there is a link between human health and soil health? Please explain. Probe for:

- Associations between human health and water, air, plants, animals, etc.

7. Do you think human health should be considered in soil health laws? Why or why not?

8. Why do you think human health is not included in current legislation?

Probe for:

- What are some current barriers?

\section{Process Questions}

9. What are the strategies or programs your organization/state are involved in that promote healthy soils? Probe for:

- What is the vision/goals of this legislation?

- Actions/interventions associated with program/policy?

- Target audience? Farmers, researchers, other policy makers, general public? 
10. Have these programs been evaluated? If not, have you seen any noticeable changes to soil health or practices since the introduction of the law?

Probe for:

- Is the policy meeting intended goals? Why or why not?

11. What are some challenges/barriers you've encountered in adopting soil health legislation?

12. State soil health legislation has increased in the last couple years; do you have any insight into this trend?

Probe for:

- Many states have soil health programs, but do not have soil health legislation. Do you think soil health legislation is important to improve soil health practices?

\section{Actor Questions}

13. Who are the key partners helping to support/fund these programs in your state?

Probe for:

- What disciplines/fields are working together on these policies?

- Any inclusion of public health professionals? 